\title{
Metode Dakwah Rasulullah SAW dan IKMI Kota Pekanbaru; Sebuah Pendekatan Kuantitatif
}

\author{
Pipir Romadi \\ Universitas Islam Negeri (UIN) Sultan Syarif Kasim Riau \\ Jl. H.R Soebrantas, Tampan, Pekanbaru 28293 \\ Email: pipir.romadi@uin-suska.ac.id
}

\begin{abstract}
IKMI Pekanbaru City as an independent preaching agency focused on carrying out missionary mission. Efforts of preachers in preaching to the community in general can be said to be good, but seeing the results achieved are not so optimal, while there have been many methods of preaching that have been exemplified by the Prophet Muhammad. This study aims to determine the intensity of IKMI preachers in applying the method of propaganda Rasulullah SAW. The methodology used in this research is descriptive quantitative percentages. The research sample used in this study was $10 \%$ of the total number of preachers namely 650 people. From the results of the study it could be concluded that $88.87 \%$ of the IKMI applied the propaganda method of the Prophet Muhammad. In its application, the preachers preach by the method of preaching alHikmah, which is delivering the da'wah by adjusting the methods, materials and conditions of mad'u, preaching is carried out continuously, consistently, and does not discuss matters that are khilafiyyah. Preaching by the method of Mau'izhah al Hasanah the preachers preach by giving advice and warnings gently, not opening the disgrace of others, trying to position themselves as role models and conduct worship training to mad'u. While the al-Mujadalah method, the preachers carry out discussion activities.
\end{abstract}

Keywoard: Metode Dakwah

Abstrak: IKMI Kota Pekanbaru sebagai lembaga dakwah yang berstatus independent fokus mengemban misi dakwah. Usaha para da'i dalam berdakwah kepada masyarakat secara umum dapat dikatakan baik, tetapi melihat hasil yang dicapai belum begitu maksimal, sementara telah banyak metode-metode dakwah yang telah dicontohkan oleh Rasulullah SAW. Penelitian ini bertujuan mengetahui intensitas para da'i IKMI dalam menerapkan metode dakwah Rasulullah SAW. Metodologi yang digunakan dalam penelitian ini adalah deskriptif kuantitatif persentase. Sampel penelitian yang digunakan dalam penelitian ini $10 \%$ dari jumlah da'i yaitu 650 orang, Dari hasil penelitian dapat disimpulkan bahwa 88,87 \% da'I IKMI menerapkan Metode dakwah Rasulullah SAW. Dalam penerapannya para da'i berdakwah dengan metode dakwah al-Hikmah, yaitu menyampaikan dakwah dengan menyesuaikan antara metode, materi dan kondisi mad'u, dakwah dilakukan secara berkesinambungan, konsisten, serta tidak membahas hal-hal yang bersifat khilafiyyah. Berdakwah dengan metode Mau'izhah al Hasanah para da'i menyampaikan dakwah dengan cara memberikan nasihat dan peringatan dengan lemah lembut, tidak membuka aib orang lain, berupaya memposisikan diri mereka sebagai tauladan dan melakukan pelatihan ibadah kepada mad'u. Sedangkan dengan metode al-Mujadalah, para da'i melakukan kegiatan diskusi.

Kata Kunci: Metode Dakwah 


\section{Pendahuluan}

Islam sebagai agama dakwah yang artinya agama yang selalu mendorong pemeluknya untuk senantiasa aktif melakukan kegiatan dakwah. ${ }^{1}$ Maju mundurnya umat Islam sangat tergantung dan berkaitan erat dengan kegiatan dakwah yang dilakukannya, ${ }^{2}$ karena itu al-Qur'an menyebut kegiatan dakwah dengan Ahsanul Qaul. ${ }^{3}$ Firman Allah SWT :

"Siapakah yang lebih baik perkataannya daripada orang yang menyeru kepada Allah, mengerjakan amal yang saleh, dan berkata: "Sesungguhnya aku Termasuk orang-orang yang menyerah diri?" (QS. Fushilat $41: 33$ )

Berdasarkan ayat di atas dapat disimpulkan bahwa dakwah menempati posisi penting dalam Islam. Umat Islam harus konsisten dalam menjalankan misi dakwah tersebut. Jika tidak kegiatan dakwah akan mengalami kemunduran terutama apabila berhadapan dengan kemajuan teknologi komunikasi di era globalisasi yang tidak dapat dibendung lagi. Umat Islam harus dapat memilih dan memilah serta menyaring informasi sehingga tidak bertentangan dengan nilai-nilai Islam. Oleh karena merupakan suatu kebenaran, maka Islam harus tersebar luas dan penyampaian kebenaran tersebut merupakan tanggung jawab umat Islam secara keseluruhan.

Dakwah dapat dipandang sebagai aktualisasi iman yang dimanifestasikan dalam suatu sistem kegiatan manusia beriman di bidang kemasyarakatan. Dakwah dilaksanakan secara teratur untuk mempengaruhi cara merasa, berpikir, bersikap, dan bertindak dari manusia pada dataran kenyataan individual dan sosiokultural guna mengusahakan terwujudnya ajaran Islam dalam semua segi kehidupan dengan menggunakan cara-cara tertentu. ${ }^{4}$

${ }^{1}$ M. Masyhur Amin, Dakwah Islam dan Pesan Moral (Jakarta: Al-Amin Press, 1997), 8.

2 Didin Hafinuddin, Dakwah Aktual (Jakarta: Gema Insani Press, 1998), Cet 3, 76.

${ }^{4}$ Amrullah Ahmad, Dakwah Islam dan Perubahan Sosial (Yogyakarta: Prisma Duta, 1983), 4.
Rasulullah SAW adalah sosok pribadi yang sangat berhasil dalam kedudukannya sebagai model kehidupan manusia yang layak diteladani oleh para pengikutnya hingga akhir zaman. ${ }^{5}$ Beliau bekerja keras mengembangkan serta menyebarluaskan ajaran Islam kepada umat dengan tingkat keberhasilan yang luar biasa melalui berbagai macam metode dakwahnya.

Metode yang dilakukan oleh Rasulullah SAW dalam berdakwah pada mulanya adalah "personal approach" atau pendekatan individu yaitu mengumpulkan kaum karib kerabatnya, namun berkembang melalui pendekatan kolektif seperti yang beliau lakukan waktu berdakwah ke Thaif dan kesempatan yang digunakan pada saat musim haji. Beliau melaksanakan dakwahnya dengan mengajak kaum muslimin kepada tauhid secara lebih terbuka. ${ }^{6}$

$$
\text { Berdasarkan teladan yang }
$$
ditunjukkan oleh Rasulullah SAW, maka dakwah haruslah dikemas dengan cara dan metode yang tepat. Dakwah harus ditampilkan secara aktual, faktual, dan kontekstual. Aktual dalam arti memecahkan masalah yang kekinian dan hangat di tengah masyarakat. ${ }^{7}$ Rasulullah SAW sebagai salah satu contoh serta panutan dalam pengembangan dakwah Islam menunjukkan tingkat keberhasilan yang sangat luar biasa, sehingga dakwah berkembang dengan baik melalui metode-metode yang beliau lakukan. Oleh sebab itu, para da'i haruslah memilih cara dan metode yang tepat sebagaimana yang telah dicontohkan oleh Rasulullah SAW agar dakwah menjadi aktual, faktual, dan kontekstual.

Salah satu lembaga dakwah yang bergerak mengemban misi dakwah ialah IKMI Kota Pekanbaru. Lembaga ini memiliki banyak jumlah da'i, masjid dan

\footnotetext{
${ }^{5}$ Munzier Suparta dan Harjani Hefni, Metode Dakwah (Jakarta: Kencana, 2009), Cet ke 3, 204.

6 R.B Khatib Pahlawan Kayo, Manajemen Dakwah dari Dakwah Konvensional Menuju Dakwah Professional (Jakarta: Amzah, 2007), 6.

${ }^{7}$ Munzier Suparta dan Harjani Hefni, Metode Dakwah, ix.
} 
musholla yang menjadi anggotanya. Hal ini sangat membantu dalam pengembangan dakwah khususnya di Kota Pekanbaru.

Dewasa ini, perjalanan dakwah khususnya di Pekanbaru menunjukkan perkembangan yang baik. Secara kuantitas sangat banyak jumlah para da'i dan da'iah dari lembaga-lembaga dakwah maupun personal salah satu lembaga dakwah adalah IKMI Kota Pekanbaru. Usaha para da'i dalam berdakwah kepada masyarakat secara umum dapat dikatakan baik. Banyak para da'i IKMI sudah memenuhi kelayakkan dalam menyampaikan materi-materi dakwah, tetapi belum mampu menerapkan strategi dalam dakwah yang tepat baik pemahaman mereka terhadap mad' $u$ maupun penggunaan metode berdakwah sehingga membuat perkembangan dakwah menjadi lebih efektif.

Untuk itu mengetahui intensitas penerapan metode dakwah Rasulullah SAW yang dilakukan oleh para da'i IKMI Kota Pekanbaru, dilakukan suatu penelitian dengan judul "Penerapan Metode Dakwah Rasulullah SAW dalam Pelaksanaan Dakwah oleh Para Da'i IKMI Kota Pekanbaru".

Penelitian ini dilakukan melalui pendekatan kuantitatif dengan subjek penelitian adalah para da'i IKMI dengan menetapkan sampel $10 \%$ dari jumlah populasi dan menggunakan teknik random sampling. ${ }^{8}$

\section{Hasil dan Pembahasan}

\section{Intensitas Penerapan Metode Dakwah Rasulullah Saw oleh Da'i IKMI Kota Pekanbaru}

Penulis mendiskripsikan tentang beberapa metode dakwah Rasulullah SAW yang diterapkan oleh para da'i IKMI Kota Pekanbaru. Untuk memastikan bahwa penerapan metode dakwah Rasulullah SAW benar-benar dilakukan oleh para da'i IKMI

8 Sarapiah Faisal, Format-format Penelitian Sosial, (Jakarta : Rajawali Press, 2010), cet ke 10, hal 63.
Kota Pekanbaru, dapat dilihat dalam tabel berikut :

TABEL IV

TINGKAT PENDIDIKAN DA'I IKMI KOTA PEKANBARU (RESPONDEN)

\begin{tabular}{|c|l|c|c|}
\hline NO & $\begin{array}{l}\text { JENJANG } \\
\text { PENDIDIKAN }\end{array}$ & FREKUENSI & PERSENTASE \\
\hline 1 & $\begin{array}{l}\text { Pascasarjana } \\
(\text { S2 })\end{array}$ & 7 & $10,9 \%$ \\
\hline 2 & $\begin{array}{l}\text { Sarjana/Diplo } \\
\text { ma }\end{array}$ & 48 & $73,8 \%$ \\
\hline 3 & MA Sederajat & 10 & $15,3 \%$ \\
\hline \multicolumn{2}{|l|}{ Jumlah } & $\mathbf{6 5}$ & $\mathbf{1 0 0} \%$ \\
\hline
\end{tabular}

Dari tabel di atas menunjukkan bahwa dari 65 responden penelitian da'i IKMI Kota Pekanbaru terdapat 7 orang yang tingkat pendidikannya adalah S2 Pascasarjana yaitu $10,9 \%$, sedangkan 48 orang pendidikan sarjana atau setara dengan $73,8 \%$, kemudian MA sederajat 10 orang atau 15,3\%. Jadi dapat disimpulkan rata-rata pendidikan da'i IKMI Kota Pekanbaru yang menjadi responden adalah sarjana.

TABEL V

JAWABAN DA'I TENTANG METODE DAKWAH RASULULLAH SAW

\begin{tabular}{|c|c|c|c|c|}
\hline NO & Opsi & $\begin{array}{c}\text { Alternatif } \\
\text { Jawaban }\end{array}$ & Frekuensi & $\begin{array}{c}\text { Persentase } \\
(\%)\end{array}$ \\
\hline \multirow[t]{4}{*}{1.} & A & Mengetahui & 65 & $100 \%$ \\
\hline & B & $\begin{array}{l}\text { Kurang } \\
\text { Mengetahui }\end{array}$ & 0 & 0 \\
\hline & $\mathrm{C}$ & $\begin{array}{l}\text { Tidak } \\
\text { Mengetahui }\end{array}$ & 0 & 0 \\
\hline & \multicolumn{2}{|c|}{ Jumlah } & 65 & $100 \%$ \\
\hline
\end{tabular}

Dari jawaban da'i tentang metode dakwah Rasulullah SAW berdasarkan tabel di atas menunjukkan bahwa secara keseluruhan para da'i IKMI Kota Pekanbaru benar-benar mengetahui tentang metode dakwah Rasulullah SAW. Dari hasil angket diperoleh jawaban dengan persentase $100 \%$. Sedangkan untuk persentase jawaban da'i yang menjawab kurang dan tidak mengetahui metode dakwah Rasulullah SAW adalah $0 \%$.

TABEL VI

METODE DAKWAH YANG DIGUNAKAN PARA DA'I DALAM BERDAKWAH 


\begin{tabular}{|c|c|c|c|c|}
\hline NO & $\begin{array}{c}\text { Ops } \\
\text { i }\end{array}$ & $\begin{array}{c}\text { Alternatif } \\
\text { Jawaban }\end{array}$ & $\begin{array}{l}\text { Frek } \\
\text { uensi }\end{array}$ & $\begin{array}{c}\text { Persenta } \\
\text { se (\%) }\end{array}$ \\
\hline \multirow[t]{4}{*}{2.} & $\mathrm{~A}$ & $\begin{array}{l}\text { Metode al- } \\
\text { Hikmah, al- } \\
\text { Mau'izhah al- } \\
\text { Hasanah dan al- } \\
\text { Mujadalah }\end{array}$ & 26 & $40 \%$ \\
\hline & B & $\begin{array}{l}\text { Metode al- } \\
\text { Hikmah dan al- } \\
\text { Mau'izhah al- } \\
\text { Hasanah atau } \\
\text { al-Hikmah dan } \\
\text { al-Mujadalah } \\
\text { atau al- } \\
\text { Mau'izhah al- } \\
\text { Hasanah dan al- } \\
\text { Mujadalah }\end{array}$ & 19 & $29,2 \%$ \\
\hline & $\mathrm{C}$ & $\begin{array}{l}\text { Salah satu dari } \\
\text { metode di atas }\end{array}$ & 20 & $30,8 \%$ \\
\hline & & Jumlah & 65 & $100 \%$ \\
\hline
\end{tabular}

Berdasarkan tabel di atas bahwa metode yang sering digunakan oleh para da' $\mathrm{i}$ IKMI adalah metode al-Hikmah, alMau'izhah al-Hasanah dan al-Mujadalah dengan persentase $40 \%$. Da'i yang hanya menggunakan dua metode yakni diantara Metode al-Hikmah dan al-Mau'izhah alHasanah atau al-Hikmah dan al-Mujadalah atau al-Mau'izhah al-Hasanah dan alMujadalah sebanyak 29,2 \%, dan da'i yang hanya menggunakan salah satu dari metode dengan persentase jawaban 30,8 \% lebih tinggi dari hasil jawaban opsi B.

Selain itu, untuk mengetahui bahwa para da'i menggunakan metode-metode yang dicontohkan oleh Rasulullah SAW dapat dilihat pada tabel berikut :

\section{A. Metode al-Hikmah}

\author{
TABEL VII \\ KEMAMPUAN PARA DA'I \\ MENYESUAIKAN ANTARA METODE \\ DAN MATERI DENGAN SITUASI DAN \\ KONDISI MAD'U
}

\begin{tabular}{|c|c|l|c|c|}
\hline NO & $\begin{array}{c}\text { Ops } \\
\mathbf{i}\end{array}$ & $\begin{array}{c}\text { Alternatif } \\
\text { Jawaban }\end{array}$ & $\begin{array}{c}\text { Frekue } \\
\mathbf{n s i}\end{array}$ & $\begin{array}{c}\text { Persent } \\
\text { ase } \\
(\boldsymbol{\%})\end{array}$ \\
\hline \multirow{2}{*}{3.} & $\mathrm{~A}$ & Menyesuaikan & 63 & $96,9 \%$ \\
\cline { 2 - 5 } & $\mathrm{B}$ & $\begin{array}{l}\text { Kurang } \\
\text { Menyesuaikan }\end{array}$ & 2 & $3,1 \%$ \\
\cline { 2 - 5 } & $\mathrm{C}$ & $\begin{array}{l}\text { Tidak } \\
\text { Menyesuaikan }\end{array}$ & 0 & $0 \%$ \\
\cline { 2 - 5 } & \multicolumn{2}{|c|}{ Jumlah } & 65 & $100 \%$ \\
\hline
\end{tabular}

Tabel di atas menjelaskan bahwa kemampuan para da'i menyesuaikan antara metode dan materi dengan situasi dan kondisi mad'u benar terlaksana dengan persentase jawaban 96,9 \%, sementara da'i yang kurang menyesuaikan antara metode dan materi dengan situasi dan kondisi mad'unya sekitar $3,1 \%$, jadi dapat dipahami bahwa da'i IKMI Kota Pekanbaru di dalam melakukan dakwah mereka senantiasa menyesuaikan antara metode dan materi sesuai dengan situasi dan kondisi objeknya (mad'u).

\section{TABEL VIII}

TENTANG CARA PARA DA'I MELAKSANAKAN DAKWAH

\begin{tabular}{|c|c|c|c|c|}
\hline NO & Opsi & $\begin{array}{l}\text { Alternatif } \\
\text { Jawaban }\end{array}$ & $\begin{array}{l}\text { Frek } \\
\text { uens } \\
\quad \text { i } \\
\end{array}$ & $\begin{array}{c}\text { Persenta } \\
\text { se }(\%)\end{array}$ \\
\hline \multirow[t]{4}{*}{4.} & $\mathrm{~A}$ & $\begin{array}{l}\text { Berkesinambun } \\
\text { gan dan } \\
\text { berkelanjutan }\end{array}$ & 47 & $72,3 \%$ \\
\hline & B & $\begin{array}{l}\text { Kurang } \\
\text { berkesinambung } \\
\text { an dan } \\
\text { berkelanjutan }\end{array}$ & 17 & $26,1 \%$ \\
\hline & $\mathrm{C}$ & $\begin{array}{l}\text { Tidak } \\
\text { Berkesinambun } \\
\text { gan dan } \\
\text { berkelanjutan }\end{array}$ & 1 & $1,6 \%$ \\
\hline & & Jumlah & 65 & $100 \%$ \\
\hline
\end{tabular}

Dalam berdakwah hendaknya dilakukan secara berkesinambungan dan berkelanjutan agar dakwah berjalan dengan efektif dan efesien. Berdasarkan data dari tabel diatas dapat diketahui bahwa para da'i IKMI Kota Pekanbaru melaksanakan dakwah secara berkelanjutan dan berkesinambungan, ini dapat di lihat dari jumlah persentase jawaban 72,3 \%, sementara da'i yang berdakwah kurang berkelanjutan dan berkesinambungan ada $26,1 \%$ dan da'i yang 
berdakwah secara tidak berkesinambungan dan berkelanjutan sekitar 1,6\%.

TABEL IX

\section{KONSISTENSI PARA DA'I MEMBERIKAN MATERI DAKWAH YANG BERKELANJUTAN}

\begin{tabular}{|c|c|c|c|c|}
\hline NO & Opsi & $\begin{array}{c}\text { Alternatif } \\
\text { Jawaban }\end{array}$ & Frekuensi & $\begin{array}{c}\text { Persenta } \\
\text { se }(\%)\end{array}$ \\
\hline \multirow[t]{4}{*}{5 . } & A & Ia & 28 & $43 \%$ \\
\hline & B & $\begin{array}{l}\text { Kadang- } \\
\text { kadang }\end{array}$ & 36 & $55,4 \%$ \\
\hline & $\mathrm{C}$ & Tidak & 1 & $1,6 \%$ \\
\hline & \multicolumn{2}{|c|}{ Jumlah } & 65 & $100 \%$ \\
\hline
\end{tabular}

Berdasarkan data diatas konsistensi para da'i IKMI Kota Pekanbaru dalam memberikan materi dakwah yang berkelanjutan lebih dominan kadang-kadang terlaksana dengan hasil persentase jawaban $55,4 \%$, sementara da'i yang selalu dan sering konsisten dalam memberikan materi dakwah yang berkelanjutan sekitar $43 \%$, untuk jawaban tidak $1,6 \%$ jadi dapat diketahui bahwa para da'i IKMI Kota Pekanbaru berdakwah kadang-kadang menyampaikan dakwah dengan materi yang berkelanjutan atau kontinue sinergi antara materi pertama dan seterusnya.

\section{TABEL $X$}

INTENSITAS PARA DA'I

MELAKSANAKAN PELATIHAN DAN PRAKTIK IBADAH

\begin{tabular}{|c|c|l|c|c|}
\hline NO & Opsi & $\begin{array}{l}\text { Alternatif } \\
\text { Jawaban }\end{array}$ & $\begin{array}{c}\text { Frekuen } \\
\text { si }\end{array}$ & $\begin{array}{c}\text { Persentase } \\
(\mathbf{\%})\end{array}$ \\
\hline 6.6 & $\mathrm{~A}$ & Sering & 17 & $26,1 \%$ \\
\cline { 2 - 5 } & $\mathrm{B}$ & $\begin{array}{l}\text { Kadang- } \\
\text { kadang }\end{array}$ & 48 & $73,9 \%$ \\
\cline { 2 - 5 } & $\mathrm{C}$ & $\begin{array}{l}\text { Tidak } \\
\text { pernah }\end{array}$ & 0 & $0 \%$ \\
\cline { 2 - 5 } & \multicolumn{2}{|c|}{ Jumlah } & 65 & $100 \%$ \\
\hline
\end{tabular}

Tabel di atas menjelaskan bahwa intensitas para da'i IKMI Kota Pekanbaru melaksanakan pelatihan dan praktek ibadah dalam berdakwah itu jarang dilakukan dengan melihat hasil jawaban da'i 73,9 \% menjawab kadang-kadang, sementara 26,1 $\%$ para da'i sering melakukan pelatihan dan praktik ibadah, kemudian $0 \%$ tidak pernah melakukannya.

TABEL XI

CARA PARA DA'I MENGHINDARI PERSELISIHAN DALAM BERDAKWAH

\begin{tabular}{|c|c|l|c|c|}
\hline NO & Opsi & \multicolumn{1}{|c|}{$\begin{array}{c}\text { Alternatif } \\
\text { Jawaban }\end{array}$} & $\begin{array}{c}\text { Freku } \\
\text { ensi }\end{array}$ & $\begin{array}{c}\text { Persent } \\
\text { ase (\%) }\end{array}$ \\
\hline 7. & A & $\begin{array}{l}\text { Tidak membahas } \\
\text { yang bersifat } \\
\text { khilafiyyah }\end{array}$ & 50 & $77 \%$ \\
\cline { 2 - 5 } & $\mathrm{B}$ & $\begin{array}{l}\text { Kadang yang } \\
\text { membahas } \\
\text { bersifat } \\
\text { khilafiyyah }\end{array}$ & 12 & $18,4 \%$ \\
\cline { 2 - 5 } & $\begin{array}{l}\text { Membahas yang } \\
\text { bersifat } \\
\text { khilafiyyah }\end{array}$ & 3 & $4,6 \%$ \\
\hline \multicolumn{3}{|l|}{ Jumlah } & 65 & $100 \%$ \\
\hline
\end{tabular}

Tabel di atas menjelaskan bahwa para da'i IKMI Kota Pekanbaru menghindari perselisihan dalam berdakwah dengan berupaya tidak membahas hal-hal yang bersifat khilafiyyah dengan jumlah peresentase jawaban $77 \%$, sedangkan 18,4 $\%$, da'i kadang membahas yang bersifat khilafiyyah dan 4,6\% da'i membahas hal-hal yang bersifat khilafiyyah. Dari data diatas dapat diketahui bahwa para da'i IKMI Kota Pekanbaru menghindari perselisihan dengan tidak membahas yang sifatnya khilafiyyah.

\section{B. Metode al-Mau'izhah al-Hasanah}

TABEL XII

PENDEKATAN PARA DA'I DALAM MENYAMPAIKAN DAKWAH

\begin{tabular}{|c|c|c|c|c|}
\hline $\begin{array}{l}\mathbf{N} \\
\mathbf{O}\end{array}$ & Opsi & $\begin{array}{c}\text { Alternatif } \\
\text { Jawaban }\end{array}$ & Frekuensi & $\begin{array}{c}\text { Persenta } \\
\text { se }(\%)\end{array}$ \\
\hline \multirow[t]{4}{*}{8.} & A & $\begin{array}{l}\text { Lemah } \\
\text { lembut }\end{array}$ & 43 & $66,1 \%$ \\
\hline & B & $\begin{array}{l}\text { Kadang- } \\
\text { kadang } \\
\text { lemah } \\
\text { lembut }\end{array}$ & 22 & $33,9 \%$ \\
\hline & $\mathrm{C}$ & $\begin{array}{l}\text { Tidak } \\
\text { lemah } \\
\text { lembut }\end{array}$ & 0 & $0 \%$ \\
\hline & & umlah & 65 & $100 \%$ \\
\hline
\end{tabular}

Tabel di atas menjelaskan bahwa pendekatan para da'i IKMI Kota Pekanbaru dalam menyampaikan dakwah yaitu secara 
lemah lembut dengan jumlah persentase jawaban $66,1 \%$, sedangkan da'i IKMI yang hanya menjawab kadang-kadang lemah lembut dalam menyampaikan dakwah sebanyak 33,9\%, dan $0 \%$ untuk jawaban tidak lemah lembut. Dari data di atas dapat disimpulkan bahwa pendekatan para da'i IKMI Kota Pekanbaru dalam menyampaikan dakwah lebih banyak dengan cara yang lemah lembut ketimbang dengan yang kadang-kadang dan tidak lemah lembut.

TABEL XIII

INTENSITAS PARA DA'I MEMBUKA AIB ORANG LAIN DALAM BERDAKWAH

\begin{tabular}{|c|c|c|c|c|}
\hline NO & Opsi & $\begin{array}{c}\text { Alternatif } \\
\text { Jawaban }\end{array}$ & $\begin{array}{c}\text { Frekuen } \\
\text { si }\end{array}$ & $\begin{array}{c}\text { Persentase } \\
(\%)\end{array}$ \\
\hline \multirow[t]{4}{*}{9.} & A & $\begin{array}{l}\text { Tidak } \\
\text { pernah }\end{array}$ & 57 & $87,7 \%$ \\
\hline & B & Pernah & 8 & $12,3 \%$ \\
\hline & $\mathrm{C}$ & Sering & 0 & $0 \%$ \\
\hline & \multicolumn{2}{|c|}{ Jumlah } & 65 & $100 \%$ \\
\hline
\end{tabular}

Tabel di atas menjelaskan bahwa para da'i ketika ditanya apakah pernah membuka aib orang lain dalam berdakwah sebanyak 87,7 \% da'i IKMI Kota Pekanbaru menjawab tidak pernah, sementara da'i IKMI Kota Pekanbaru yang pernah membuka aib orang dalam berdakwah $12,3 \%$, dan $0 \%$ yang menjawab sering. Dari data diatas dapat di simpulkan bahwa para da'i IKMI Kota Pekanbaru lebih banyak menjawab tidak pernah membuka aib orang lain didalam menyampaikan dakwah.

TABEL XIV

UPAYA PARA DA'I MENJADI TAULADAN BAGI MAD'U

\begin{tabular}{|c|c|c|c|c|}
\hline NO & Opsi & $\begin{array}{l}\text { Alternatif } \\
\text { Jawaban }\end{array}$ & Frekuensi & $\begin{array}{c}\text { Persenta } \\
\text { se }(\%)\end{array}$ \\
\hline \multirow[t]{4}{*}{10.} & A & Berupaya & 65 & $100 \%$ \\
\hline & $\mathrm{B}$ & $\begin{array}{l}\text { Kurang } \\
\text { Berupaya }\end{array}$ & 0 & $0 \%$ \\
\hline & $\mathrm{C}$ & $\begin{array}{l}\text { Tidak } \\
\text { Berupaya }\end{array}$ & 0 & $0 \%$ \\
\hline & \multicolumn{2}{|c|}{ Jumlah } & 65 & $100 \%$ \\
\hline
\end{tabular}

Salah satu upaya yang dilakukan oleh para da'i IKMI Kota Pekanbaru untuk menerapkan metode dakwah Rasulullah SAW ialah bisa menjadi tauladan bagi mad'unya. Dari hasil data yang penulis dapatkan menyatakan bahwa para da'i IKMI Kota Pekanbaru selalu berupaya untuk menjadi tauladan bagi mad'unya, dengan persentase $100 \%$ menjawab berupaya.

\section{Metode al-Mujadalah}

\section{TABEL XV}

\section{INTENSITAS PARA DA'I MELAKUKAN DISKUSI DENGAN MAD'U}

\begin{tabular}{|c|c|c|c|c|}
\hline NO & Opsi & $\begin{array}{l}\text { Alternatif } \\
\text { Jawaban }\end{array}$ & Frekuensi & $\begin{array}{c}\text { Persenta } \\
\text { se }(\%)\end{array}$ \\
\hline \multirow[t]{4}{*}{11.} & $\mathrm{~A}$ & Sering & 37 & $57 \%$ \\
\hline & B & $\begin{array}{l}\text { Kadang- } \\
\text { kadang }\end{array}$ & 28 & $43 \%$ \\
\hline & $\mathrm{C}$ & $\begin{array}{l}\text { Tidak } \\
\text { Pernah }\end{array}$ & 0 & $0 \%$ \\
\hline & \multicolumn{2}{|c|}{ Jumlah } & 65 & $100 \%$ \\
\hline
\end{tabular}

Di era sekarang ini diskusi dalam dakwah menjadi hal yang populer dilakukan oleh banyak da'i dan tidak menutup kemungkinan da'i IKMI Kota Pekanbaru melakukan hal itu juga. Dari hasil data yang penulis dapatkan $57 \%$ da'i IKMI Kota Pekanbaru sering melakukan diskusi dalam berdakwah dan $43 \%$ da'i kadang-kadang atau jarang melakukan diskusi dalam berdakwah sedangkan unruk jawaban opsi tidak pernah $0 \%$.

\section{TABEL XVI}

PERSEPSI PARA DA'I TENTANG EFEKTIFITAS DISKUSI DALAM BERDAKWAH

\begin{tabular}{|c|c|c|c|c|}
\hline NO & Opsi & $\begin{array}{c}\text { Alternatif } \\
\text { Jawaban }\end{array}$ & $\begin{array}{c}\text { Frekuen } \\
\text { si }\end{array}$ & $\begin{array}{c}\text { Persentase } \\
(\%)\end{array}$ \\
\hline \multirow[t]{4}{*}{12.} & A & Efektif & 60 & $92,3 \%$ \\
\hline & B & $\begin{array}{l}\text { Kurang } \\
\text { Efektif }\end{array}$ & 5 & $7,7 \%$ \\
\hline & $\mathrm{C}$ & $\begin{array}{l}\text { Tidak } \\
\text { Efektif }\end{array}$ & 0 & $0 \%$ \\
\hline & \multicolumn{2}{|c|}{ Jumlah } & 65 & $100 \%$ \\
\hline
\end{tabular}


Melihat dari hasil persentase pada tabel XVI bahwa da'i IKMI Kota Pekanbaru sering melakukan diskusi dalam berdakwah, berarti hal ini menunjukkan sebagian da'i sepakat bahwa diskusi sangat efektif dilakukan. Dari hasil pengumpulan data yang penulis lakukan memang benar banyak da'i yang menyatakan bahwa diskusi sangat efektif dilakukan dalam berdakwah dan ini dapat di lihat dengan jumlah persentase jawaban da'i yang menjawab efektif 92,3 \%, sementara da'i yang menyatakan bahwa diskusi kurang efektif untuk dilakukan hanya $7,7 \%$, dan $0 \%$ untuk jawaban tidak efektif.

\section{TABEL XVII \\ INTENSITAS PARA DA'I MEMBERIKAN KESEMPATAN KEPADA MAD'U UNTUK BERPENDAPAT}

\begin{tabular}{|c|c|l|c|c|}
\hline NO & Opsi & $\begin{array}{l}\text { Alternatif } \\
\text { Jawaban }\end{array}$ & $\begin{array}{c}\text { Frekuen } \\
\text { si }\end{array}$ & $\begin{array}{c}\text { Persentase } \\
(\%)\end{array}$ \\
\hline \multirow{3}{*}{ 13. } & A & Sering & 30 & $46,1 \%$ \\
\cline { 2 - 5 } & B & $\begin{array}{l}\text { Kadang- } \\
\text { kadang }\end{array}$ & 35 & $53,9 \%$ \\
\cline { 2 - 5 } & C & $\begin{array}{l}\text { Tidak } \\
\text { pernah }\end{array}$ & 0 & $0 \%$ \\
\cline { 2 - 5 } & \multicolumn{2}{|c|}{ Jumlah } & 65 & $100 \%$ \\
\hline
\end{tabular}

Tabel di atas menjelaskan intensitas para da'i memberikan kesempatan kepada mad'u berpendapat. Dari hasil jawaban menyatakan bahwa da'i IKMI Kota Pekanbaru yang sering memberikan kesempatan kepada mad'u berpendapat dalam berdakwah yaitu 46,1 \%, sementara da'i IKMI Kota Pekanbaru hanya kadangkadang memberikan kesempatan kepada mad' $u$ untuk berpendapat yaitu 53,9\%, dan 0 $\%$ untuk jawaban tidak. Dari data diatas dapat disimpulkan bahwa para da'i IKMI Kota Pekanbaru hanya kadang-kadang saja memberikan kesempatan kepada mad'u untuk berpendapat.

\section{Analisis tentang Intensitas Penerapan Metode Dakwah Rasulullah Saw oleh Para Da'i IKMI Kota Pekanbaru}

Untuk mengatahui lebih lanjut intensitas penerapan metode dakwah Rasulullah SAW dalam pelaksanaan dakwah oleh para da'i IKMI Kota Pekanbaru dilakukan analisis sebagai berikut.

A. Tingkat penerapan metode dakwah Rasulullah SAW oleh para da'i IKMI dalam berdakwah.

Berdasarkan data sebelumnya maka hasil rekapitulasi sebagai berikut :

TABEL XVIII

HASIL REKAPITULASI ANGKET DA'I IKMI KOTA PEKANBARU

\begin{tabular}{|c|c|c|c|c|c|c|c|c|c|}
\hline \multirow{2}{*}{$\begin{array}{l}\mathbf{N} \\
\mathbf{O}\end{array}$} & \multirow{2}{*}{ TAB } & \multicolumn{2}{|c|}{$\mathbf{A}$} & \multicolumn{2}{|c|}{ B } & \multicolumn{2}{|c|}{ C } & \multicolumn{2}{|c|}{ JUMLAH } \\
\hline & & $\mathbf{F}$ & $\mathbf{P}$ & $\mathbf{F}$ & $\mathbf{P}$ & $\mathbf{F}$ & $\mathbf{P}$ & $\mathbf{F}$ & $\mathbf{P}$ \\
\hline 1. & $\mathrm{~V}$ & 65 & $100 \%$ & 0 & $0 \%$ & 0 & $0 \%$ & 65 & $100 \%$ \\
\hline 2. & VI & 26 & $40 \%$ & 19 & $29,2 \%$ & 20 & $\begin{array}{c}30,8 \\
\%\end{array}$ & 65 & $100 \%$ \\
\hline 3. & VII & 63 & $96,9 \%$ & 2 & $3,1 \%$ & 0 & $0 \%$ & 65 & $100 \%$ \\
\hline 4. & VIII & 47 & $72,3 \%$ & 17 & $26,1 \%$ & 1 & $\begin{array}{c}1,6 \\
\%\end{array}$ & 65 & $100 \%$ \\
\hline 5. & IX & 29 & $43 \%$ & 36 & $55,4 \%$ & 1 & $\begin{array}{c}1,6 \\
\%\end{array}$ & 65 & $100 \%$ \\
\hline 6. & $\mathrm{X}$ & 17 & $26,1 \%$ & 48 & $73,9 \%$ & 0 & $0 \%$ & 65 & $100 \%$ \\
\hline 7. & XI & 50 & $77 \%$ & 12 & $18,4 \%$ & 3 & $\begin{array}{c}4,6 \\
\%\end{array}$ & 65 & $100 \%$ \\
\hline 8. & XII & 43 & $66,1 \%$ & 22 & $33,9 \%$ & 0 & $0 \%$ & 65 & $100 \%$ \\
\hline 9. & XIII & 57 & $87,7 \%$ & 8 & $12,3 \%$ & 0 & $0 \%$ & 65 & $100 \%$ \\
\hline 10. & XIV & 65 & $100 \%$ & 0 & $0 \%$ & 0 & $0 \%$ & 65 & $100 \%$ \\
\hline 11. & $\mathrm{XV}$ & 37 & $57 \%$ & 28 & $43 \%$ & 0 & $0 \%$ & 65 & $100 \%$ \\
\hline 12. & XVI & 60 & $92,3 \%$ & 5 & $7,7 \%$ & 0 & $0 \%$ & 65 & $100 \%$ \\
\hline 13. & XVII & 30 & $46,1 \%$ & 35 & $53,9 \%$ & 0 & $0 \%$ & 65 & $100 \%$ \\
\hline \multicolumn{2}{|c|}{ JUMLAH } & 588 & $69,6 \%$ & $\begin{array}{c}23 \\
2 \\
\end{array}$ & $27,4 \%$ & 25 & $\begin{array}{c}3,0 \\
\%\end{array}$ & 845 & $100 \%$ \\
\hline
\end{tabular}

Berikut akan dipaparkan analisis terhadap masing-masing item berdasarkan data jawaban responden yaitu da'i IKMI Kota Pekanbaru yang dibuat berdasarkan frekuensi dan persertase masing-masing opsi, analisa selengkapnya dapat dilihat dibawah ini :

Tabel V menunjukkan jawaban para da'i tentang metode dakwah Rasulullah SAW keseluruhan menjawab mengetahui tentang metode dakwah Rasulullah SAW. Hal ini dapat dilihat dari besarnya persentase yang memilih opsi A (mengetahui) sebesar 100 $\%$. Atau 65 orang.

Tabel VI menunjukkan metode dakwah yang digunakan para da'i dalam berdakwah. Dalam hal ini sebagian besar da'i menggunakan metode al-Hikmah, alMau'izhah dan al-Mujadalah. Hal ini dapat dilihat dari besarnya persentase da'i yang memilih opsi A (metode al-Hikmah, al- 
Mau'izhah dan al-Mujadalah) sebesar $40 \%$ atau 26 orang.

Tabel VII menunjukkan kemampuan para da'i menyesuaikan antara metode dan materi dengan situasi kondisi mad'u, sebagian besar da'i menjawab menyesuaikan. Hal ini didukung dari besaran persentase yang memilih opsi A (menyesuaikan) sebesar $96,9 \%$ atau 63 orang.

Tabel VIII memperlihatkan tentang cara para da'i melaksanakan dakwah, sebagian besar da'i menjawab berkesinambungan dan berkelanjutan. Hal ini dapat dilihat dari besarnya persentase yang memilih opsi A (berkesinambungan dan berkelanjutan) sebesar 72,3\% atau 47 orang.

Tabel IX memperlihatkan konsistensi para da'i memberikan materi dakwah yang berkelanjutan, sebagian besar da'i menjawab kadang-kadang. Hal ini dapat dilihat dari besarnya persentase yang memilih opsi B (kadang-kadang) sebesar 55,4\% atau 36 orang.

Tabel X menunjukkan intensitas para da'i melaksanakan pelatihan dan praktik ibadah, sebagian besar da'i menjawab kadang-kadang. Hal ini dapat dilihat dari besarnya persentase yang memilih opsi B (kadang-kadang) sebesar 73,9 \% atau 48 orang.

Tabel XI memperlihatkan cara para da'i menghindari perselisihan dalam berdakwah, sebagian besar da'i menjawab tidak membahas hal yang bersifat khilafiyyah. Hal ini dapat dilihat dari besarnya persentase yang memilih opsi A (tidak membahas hal yang bersifat khilafiyyah) sebesar $77 \%$ atau 50 orang.

Tabel XII memperlihatkan pendekatan para da'i dalam menyampaikan dakwah, sebagian besar da'i menjawab lemah lembut. Hal ini dapat dilihat dari besarnya persentase yang memilih opsi A (lemah lembut) sebesar 66,1\% atau 43 orang.

Tabel XIII memperlihatkan intensitas para da'i membuka aib orang lain dalam berdakwah, sebagian besar da'i menjawab tidak pernah. Hal ini dapat dilihat dari besarnya persentase yang memilih opsi A (tidak pernah) sebesar 87,7\% atau 57 orang.

Tabel XIV memperlihatkan upaya para da'i menjadi tauladan bagi mad'u, secara keseluruhan da'i menjawab berupaya. Hal ini dapat dilihat dari besarnya persentase yang memilih opsi A (berupaya) sebesar 100 $\%$ atau 65 orang.

Tabel XV memperlihatkan intensitas para melakukan diskusi dengan mad'u, sebagian besar da'i menjawab sering. Hal ini dapat dilihat dari besarnya persentase yang memilih opsi A (sering) sebesar $57 \%$ atau 37 orang.

Tabel XVI memperlihatkan persepsi para da'i tentang efektifitas diskusi dalam berdakwah, sebagian besar da'i menjawab efektif. Hal ini dapat dilihat dari besarnya persentase yang memilih opsi A (efektif) sebesar $92,3 \%$ atau 60 orang.

Tabel XVII memperlihatkan intensitas para da'i memberikan kesempatan kepada mad' $u$ berpendapat, sebagian besar da'i menjawab kadang-kadang. Hal ini dapat dilihat dari besarnya persentase yang memilih opsi B (kadang-kadang) sebesar $53,9 \%$ atau 35 orang.

Berdasarkan angka-angka diperoleh di atas, maka dapat dimasukkan dan diolah dengan rumus sebagai berikut :

$$
\mathrm{P}=\frac{F}{N} \times 100
$$

Diketahui :

$$
\begin{array}{ll}
\text { Frekuensi } & \mathrm{F}=2253 \\
\text { Total Responden } & \mathrm{N}=845 \quad \text { Nilai }
\end{array}
$$

ideal $\mathrm{N}=845 \times 3=2535$

Maka dapat dimasukkan ke dalam rumus :

$$
\begin{aligned}
: \mathrm{P} & =\frac{F}{N} \times 100 \% \\
\mathrm{P} & =\frac{2253}{2535} \times 100 \% \\
\mathrm{P} & =\frac{225300}{2535} \\
\mathrm{P} & =\mathbf{8 8 , 8 7} \%
\end{aligned}
$$

Persentase rata-rata yang diperoleh merupakan persentase bagaimana penerapan metode dakwah Rasulullah SAW dalam pelaksanaan dakwah oleh para da'i IKMI Kota Pekanbaru. Untuk mengetahui kategori persentase di atas digunakan standar pengukuran sebagai berikut : 
1. $76-100 \%$ termasuk dalam kategori tinggi.

2. $56-75 \%$ termasuk dalam kategori sedang.

3. $0-55 \%$ termasuk dalam kategori rendah.

Dari hasil rekapitulasi angket responden tersebut di atas, dapat diperoleh nilai rata-rata yaitu $\mathbf{8 8 , 8 7} \%$ dengan frekuensi tertinggi pada alternatif jawaban di opsi " $A$ " dengan jumlah persentase $69,6 \%$, jawaban di opsi "B" dengan jumlah persentase $27,4 \%$ dan jawaban di opsi " $C$ " dengan jumlah persentase $3,0 \%$.

Jika dilihat nilai rata-rata diketahui

$\mathbf{8 8 , 8 7} \%$ ini menunjukkan berada pada kategori tinggi, yaitu diantara 76-100\%. Dengan demikian dapat disimpulkan bahwa intensitas para da'i IKMI Kota Pekanbaru dalam menerapkan metode dakwah Rasulullah SAW dalam pelaksanaan dakwah dapat dikatakan mayoritas telah menerapkan metode dakwah Rasulullah SAW yaitu :

1. Metode dakwah al-Hikmah. Para da'i menyampaikan dakwah menyesuaikan antara metode dan materi dengan situasi kondisi mad'u. Menyampaikan dakwah secara berkesinambungan dan berkelanjutan. Para da'i konsistensi dalam memberikan materi dakwah yang berkelanjutan. Menghindari perselisihan berdakwah dengan tidak membahas halhal yang bersifat khilafiyyah.

2. Metode al-Mau'izhah al-Hasanah. Para da'i menyampaikan dakwah dengan cara memberikan nasehat dan peringatan dengan lemah lembut, tidak membuka aib orang lain, para da'i berupaya memposisikan diri mereka sebagai tauladan dan melakukan pelatihan ibadah mad'u.

3. Metode al-Mujadalah. Para da'i IKMI Kota Pekanbaru menyatakan bahwa diskusi sangat efektif dilakukan dalam berdakwah sehingga metode alMujadalah dengan cara berdiskusi dan memberikan kesempatan ini sering dilakukan oleh para da'i IKMI Kota Pekanbaru.

Hal ini didukung oleh pendapat Imam Muhammad Fakhruddin Al-Razi bahwa metode dakwah Rasulullah SAW diantaranya metode dakwah al-Hikmah, metode dakwah al-Mau'izhah al-Hasanah, metode dakwah al-Mujadalah. ${ }^{9}$

Pergerakkan dakwah IKMI sejatinya adalah da'i yang menjadi salah satu faktor terpenting sebagai tenaga pelaksana dakwah. Dalam persoalan teknis pelaksanaan dakwah da'i dituntut untuk memiliki kemampuan atau skill serta keterampilan untuk menghadapi medan dakwah sehingga dakwah yang disampaikan berjalan efektif dan efesien sehingga mad'u mendapatkan kepuasan batin sebagai objek dakwah. Oleh sebab itu perlu adanya upaya penerapan metode dakwah yang tepat bagi da'i IKMI Kota Pekanbaru terutama metode dakwah Rasulullah SAW.

Menurut analisis penulis berdasarkan tingginya intensitas penerapan metode dakwah Rasulullah SAW oleh para da'i IKMI yang dilihat dari hasil data yang diperoleh, penulis menilai bahwa da'i IKMI sudah berupaya menerapkan metode dakwah Rasulullah SAW, hal ini juga diungkapkan oleh pengurus IKMI Kota Pekanbaru Taslim Prawira bahwa para da'i IKMI telah berupaya melaksanakan metode dakwah yang telah diajarkan dan diaplikasikan oleh Rasulullah SAW, walaupun pada dasarnya pelaksanaan dan hasilnya belum sebegitu maksimal. Beliau mengatakan memang tidak mudah untuk melakukan hal yang sama seperti Rasulullah SAW tetapi para da'i IKMI berusaha dan berupaya melakukannya. Sejauh ini apa yang dilakukan oleh para da'i IKMI Kota Pekanbaru di dalam melaksanakan dakwah sudah hampir mendekati apa yang diaplikasikan oleh Rasulullah SAW. ${ }^{10}$

${ }^{9}$ Imam Muhammad Fakhr al-Din al-Razi Ibn al-Alamah Dhiya'i al-Din Umar, Tafsir al-Razi alMusytahar bi al-Tafsir wa Mafatihi al-Ghai, 141.

10 Wawancara, Taslim Prawira 28 Desember 
Sejatinya bahwa para da'i sesungguhnya telah menerapkan metode dan cara dakwah ala Rasulullah SAW, hanya saja untuk di era sekarang ini perlu adanya pengembangan-pengembangan lebih lanjut untuk menyesuaikan penempatan metode itu. Metode dakwah Rasulullah SAW harus dikemas secara baik dengan media yang sesuai dengan perkembangan saat ini agar pesan dakwah yang disampaikan sampai kepada mad'u. Untuk itu para da'i IKMI Kota Pekanbaru disamping mahir dalam persoalan keilmuan hendaknya mampu menguasai teknologi yang canggih dan sesuai dengan kondisi saat ini sebagai media di dalam menyampaikan dakwah, karena dakwah tidak hanya melalui mimbar saja, namun bisa lebih dari itu.

\section{B. Beberapa Faktor Tingginya Penerapan Metode Dakwah Rasulullah SAW dalam Pelaksanaan Dakwah oleh Para Da'i IKMI Kota Pekanbaru}

Penelitian ini juga ditemukan beberapa faktor yang mendorong sehingga para da'i IKMI Kota Pekanbaru dapat menerapkan metode dakwah Rasulullah SAW dalam berdakwah yaitu:

\section{Pendidikan \\ dan \\ Keagamaan. \\ Pendidikan seorang}

Pemahaman

diperlukan menyangkut

da'i sangat persoalan pemahaman mereka dalam melakukan dakwah untuk mengatur dan menggunakan metode yang tepat sesuai dengan sasaran yang dituju. Pemahaman keagamaan mereka juga akan berpengaruh terhadap efek yang ditimbulkan ketika dalam pelaksanaan dakwah. Semakin tinggi tingkat pemahaman keagamaan mereka maka mad'u semakin tinggi tingkat kepercayaan kepada da'i tersebut. Dilihat dari data yang ada rata-rata pendidikan da'i IKMI Kota Pekanbaru adalah sarjana (strata 1) yang berbasis Agama. Da'i harus mengetahui cara menyampaikan dakwah tentang Allah, alam semesta dan kehidupan, serta apa yang dihadirkan dakwah untuk memberikan solusi, terhadap problema yang dihadapi manusia, juga metode-metode yang dihadirkannya untuk menjadikan agar pemikiran dan perilaku manusia tidak salah dan tidak melenceng. ${ }^{11}$

\section{Kesadaran terhadap Kewajiban Berdakwah.}

Dakwah merupakan kewajiban serta tuntutan bagi setiap umat muslim, dalam hal ini para da'i IKMI Kota Pekanbaru memiliki kesadaran pentingnya berdakwah, melihat dari banyaknya jumlah da'i yang ada, ini menunjukkan bahwa tingginya tingkat kesadaran akan kewajiban di dalam melakukan tugas misi dakwah. Menurut bimbingan al-Qur'an dan as-Sunnah, berdakwah itu tidak boleh berhenti atau putus asa karena kurangnya sambutan ummat, sebab tugas da'i hanya mengajak, soal diterima atau tidak bukan urusan da'i. ${ }^{12}$ Berdakwah suatu tugas yang tidak bisa ditawar-tawar, suatu tugas suci yang wajib dilaksanakan kapanpun dan dimanapun, dan sekalipun ditolak, sebab tugas da'i hanya mengajak, urusan hati Allah yang mengetahui, pada intinya dakwah adalah sebuah kewajiban yang harus dilakukan.

\section{Pelatihan dan Pembinaan.}

Idaroh Kemakmuran Masjid Indonesia (IKMI) Kota Pekanbaru sering mengadakan pelatihan serta bimbingan kepada da'ida'inya, sebelum mereka berdakwah mereka terlebih dahulu diberikan pembekalanpembekalan. Pada dasarnya, banyak diantara da'i IKMI Kota Pekanbaru ini yang berlatar belakang pendidikan umum yang belum begitu menguasai ilmu agama, jadi perlu adanya pelatihan dan bimbingan kepada da' $i$ mengenai metode-metode dalam berdakwah, materi serta tata cara dalam berdakwah. Salah satunya Orientasi Da'i (ORDA) ini para da'i dibimbing oleh da'i-da'i senior. ${ }^{13}$

11 Mustafa Malaikah, Manhaj Dakwah Yusuf al-Qordhowi Harmoni antara Kelembutan dan Ketegasan (Jakarta: Pustaka Al-Kautsar, 1997), 18.

12 Al-Wisral Imam Zaidallah, Strategi Dakwah dalam Membentuk Da'i dan Khotib Professional, 12.

13 Wawancara. Taslim Prawira 28 Desember 2012. 


\section{Motivasi.}

Salah satu faktor terpenting di dalam melakukan misi dakwah adalah semangat perjuangan sesuai apa yang telah ditunjukkan oleh Rasulullah SAW. Rasulullah SAW dalam melakukan dakwah tidak ada kata menyerah, walaupun Rasulullah SAW sering dihina dan dicaci-maki bahkan dilempar dengan kotoran, namun semangat dalam melakukan dakwah tetap kokoh. Dalam melaksanakan dakwah haruslah disertai niat karena Allah SWT, bukan semata-mata karena materi ataupun pujian dan sebagainya.

Menurut M. Munir dan Wahyu Ilahi bahwa motivasi diartikan sebagai kemampuan seorang manajer atau pemimpin dakwah dalam memberikan seguah kegairahan dan kegiatan dan pengertian, sehingga para anggotanya mampu untuk mencapai tujuan organisasi. Dengan demikian motivasi merupakan dinamisator bagi para elemen dakwah yang secara ikhlas dapat merasakan, bahwa pekerjaan itu adalah kewajiban yang harus dilaksanakan. ${ }^{14}$

\section{Penutup}

Setelah disajikan dan dianalisis, dapat disimpulkan bahwa intensitas penerapan metode dakwah Rasulullah SAW oleh para da'i IKMI Kota Pekanbaru dalam berdakwah sangat tinggi dengan nilai $88,87 \%$. Ini berarti bahwa mayoritas da'i telah menerapkan metode dakwah Rasulullah SAW yakni, Metode al-Hikmah, alMau'izhah al-Hasanah, dan al-Mujadalah. Melalui metode al-Hikmah, para da'i IKMI Kota Pekanbaru menyampaikan dakwah menyesuaikan antara metode, materi dan kondisi mad'u, para da'i IKMI Kota Pekanbaru melaksanakan dakwah secara berkesinambungan dan berkelanjutan serta tidak membahas hal-hal yang bersifat khilafiyyah dalam berdakwah. Melalui metode al-Mauizhah al-Hasanah, para da'i IKMI Kota Pekanbaru menyampaikan dakwah dengan lembah lembut dengan tidak membuka aib orang lain dalam berdakwah

14 M.Munir dan Wahyu Ilahi, Manajemen Dakwah, 141. serta berupaya menjadi tauladan bagi mad'u. Melalui metode al-Mujadalah para da'i IKMI Kota Pekanbaru sering melakukan diskusi dalam berdakwah.

Tingginya intensitas penerapan metode dakwah Rasulullah SAW dalam pelaksanaan dakwah oleh para da'i IKMI Kota Pekanbaru dipengaruhi oleh tingkat pendidikan dan pemahaman keagamaan para da'i IKMI itu sendiri yang rata-rata adalah sarjana. Selain itu dipengaruhi oleh tingginya tingkat kesadaran para da'i tentang kewajiban untuk melakukan dakwah, serta da'i IKMI Kota Pekanbaru juga sering diberikan motivasi-motivasi melalui pelatihan dan pembinaan.

\section{DAFTAR PUSTAKA}

Ahmad, Amrullah.1983. Dakwah Islam dan Perubahan Sosial. Yogyakarta : Prisma Duta.

Amin, M. Masyhur. 1997. Dakwah Islam dan Pesan Moral. Jakarta : Al-Amin Press.

An-Nabiry, Fathul Bahri. 2008. Meniti Jalan Dakwah Bekal Perjuangan Para Da’i. Jakarta : Amzah.

Arif, M. 1991. Ilmu Pendidikan Islam. Jakarta: Bumi Aksara.

Arikunto, Suharsimi. 2006. Prosedur Penelitian. Rineka Cipta : Jakarta.

Collins, William. 1980. Webster's New Twentieth Century Dictionary, Noah Webster : Amerika Serikat.

Faisal, Sarapiah.2010. Format-format Penelitian Sosial. Jakarta : Rajawali Press.

Faizah dan Lalu Muchsin Effendi. 2009. Psikologi Dakwah. Jakarta : Kencana.

Hasanudin. 1996. Hukum Dakwah. Jakarta : Pedoman Ilmu Jaya. 
Hafinuddin, Didin. 1998. Dakwah Aktual. Jakarta : Gema Insani Press.

Hartono, Toni. 2011. Komunikasi Dakwah. Pekanbaru : Yayasan Pusaka Riau.

Haswir dan Ismardi Ilyas. 2011. Profil IKMI: Derap Langkah Perjuangan Dakwah di Riau. Pekanbaru : Biro Litbang IKMI Koorwil Riau.

Imam Muhammad Fakhr al-Din al-Razi Ibn al-Alamah Dhiya'i al-Din Umar.1994. Tafsir al-Razi alMusytahar bi al-Tafsir wa Mafatihi al-Ghaib, Dar al-Fikr : Lebanon .

Kayo, RB. Khatib Pahlawan. 2007. Manajemen Dakwah dari Dakwah Konvensional Menuju Dakwah Profesional. Amzah : Jakarta.

Machendrawaty, Nanih dan Aep Kusnawan. 2003. Teknik Debat dalam Islam. Bandung : Pustaka Setia.

Malaikah, Mustafa. 1907. Manhaj Dakwah Yusuf al-Qordhowi Harmoni antara Kelembutan dan Ketegasan. Jakarta: Pustaka Al-Kautsar

Muhyidin, Asep dan Agus Ahmad Safe'i. 2002. Metode Pengembangan Dakwah. Bandung : Pustaka setia.

Munir, Muhammad dan Wahyu Ilahi. 2009. Manajemen Dakwah. Jakarta : Kencana.

Mustofa, Ibrahim dkk. 1989. al-Mu'jam alWasith. Turki-Istambul : Dar alDa'wah .
Mustafa Ya'qub, Ali. 2008. Sejarah dan Metode Dakwah Nabi. Jakarta : Pustaka Firdaus.

Poerwadarminta. 1986. Kamus Besar Bahasa Indonesia. Jakarta : Balai Pustaka

Pusat Bahasa Departemen Pendidikan Nasional. 2007. Kamus Besar Bahasa Indonesia. Jakarta: Balai Pustaka.

Quthb, Sayyid. 1998. Fi Zila al-Qur'an. Kairo : Dar al-Ayuruq

Rafi'udin dan Maman Abdul Djaliel. 2001. Prinsip dan Strategi Dakwah. Bandung : Pustaka Setia.

Said, Ibnu. 1980. Al-Thabaqat .Al-Kubra Beirut : Darel-Fikr.

Saputra,Wahidin. 2011. Pengantar Ilmu Dakwah. Jakarta : Rajawali Press.

Suparta, Munzier dan Harjani Hefni. 2009. Metode Dakwah. Jakarta : Kencana.

Tafsir, Ahmad. 1995. Metodologi Pengajaran Agama Islam. Bandung : Remaja Rosdakarya.

Tasmara, Toto. 1997. Komunikasi Dakwah. Jakarta : Gaya media Pratama.

Zaidallah, Alwisral Imam. 2005. Strategi Dakwah dalam Membentuk Da'i dan Khotib professional. Jakarta : Kalam Mulia. 